Sains Malaysiana 49(1)(2020): 1-10

http://dx.doi.org/10.17576/jsm-2020-4901-01

\title{
Multifarious Roles of Feeding Behaviours in Rove Beetle, Paederus fuscipes
}

(Peranan Multifarius dalam Tingkah Laku Pemakanan Kumbang Rove, Paederus fuscipes)

\author{
WAN FATMa ZuharaH* \& Sufian Maryam
}

\begin{abstract}
The rice green leafhopper Nephotettix virescens Distant (Hemiptera: Cicadellidae), zigzag leafhopper Recilia dorsalis Motschulsky (Hemiptera: Cicadellidae), and brown planthopper Nilaparvata lugens Stål (Hemiptera: Delphacidae) are the most economically important insect pests infesting rice crop. Paederus fuscipes Curtis has been reported as the natural predator for these rice pest species in Southeast Asia. Under laboratory conditions, we evaluated the prey preference of this generalist predator when it encountered the three main agricultural pests of rice plant. $\mathrm{P}$. fuscipes typically displayed a Type II functional response for all prey species. However, at high prey densities they consumed predominantly R. dorsalis with highest attack rate on dead R. dorsalis prey. Conversely, significantly highest time was needed to handle live R. dorsalis. When various density of preys was tested simultaneously, the predator showed greater preferences towards R. dorsalis and Ni. lugens. We observed the behavioral response of $\mathrm{P}$. fuscipes predator on its prey items. Highest number of searching and capturing attempt was most frequently displayed on live $\mathrm{Ni}$. lugens prey species. Whereas, P. fuscipes spent more feeding time in consuming dead prey compared to the alive ones. Overall, P. fuscipes showed successful control of small and soft body crop pests at low prey density.
\end{abstract}

Keywords: Biological control; functional response; Paedarus; prey preference; rice pests

ABSTRAK

Lelompat daun hijau Nephotettix virescens Distant (Hemiptera:Cicadellidae), lelompat zigzag Recilia dorsalis Motschulsky (Hemiptera:Cicadellidae) dan lelompat pokok perang Nilaparvata lugens Stål (Hemiptera: Delphacidae) merupakan perosak penting ekonomi yang menyerang tanaman padi. Paederus fuscipes Curtis menghuraikan sebagai pemangsa semula jadi untuk kesemua spesies perosak padi di Asia Tenggara. Di dalam keadaan makmal, kami menilai pemilihan mangsa untuk pemangsa ini semasa berhadapan dengan tiga jenis perosak utama pertanian padi. P. fuscipes menunjukkan tindak balas fungi jenis II untuk kesemua spesies mangsa, tetapi pada kepadatan tinggi mereka lebih menggemari R. dorsalis. Kadar serangan tertinggi diperhatikan pada R. dorsalis yang telah mati. Sebaliknya, kadar masa pengendalian tertinggi diterima oleh $\mathrm{R}$. dorsalis yang hidup. Semasa pelbagai kepadatan diuji pada masa yang sama, pemangsa menunjukkan pemilihan yang lebih besar terhadap $\mathrm{R}$. dorsalis dan Ni. lugens. Kami juga memerhatikan tindak balas perlakuan oleh pemangsa P. fuscipes terhadap mangsa. Percubaan untuk mencari dan menangkap banyak ditunjukkan pada spesies mangsa Ni. lugens yang hidup. Manakala, P. fuscipes menghabiskan lebih masa makan pada mangsa yang telah mati berbanding yang masih hidup. Secara keseluruhan, P. fuscipes menunjukkan keberjayaan dalam mengawal perosak pertanian bertubuh kecil dan lembut pada kepadatan yang rendah.

Kata kunci: Kawalan biologi; Paedarus; pemilihan mangsa; perosak padi; tindak balas fungsi

\section{INTRODUCTION}

The rove beetle, Paederus sp. (Coleoptera: Staphylinidae) is an economically important predator used in controlling insect pest populations in the agro-ecosystem (Frank \& Kanamitsu 1987). Although, the genus Paederus is notorious for its vesicant paederin that causes dermatitis linearis to humans, these beetles are reckoned as effective biological control agents of crop pests (Bong et al. 2015). Paederus beetle is widely distributed around the world for instance in Europe, Asia, India, New Guinea, Africa and Australia except Antarctica (Frank \& Kanamitsu 1987; Singh \& Ali 2007). However, in Malaysia the species Paederus fuscipes Curtis is predominantly distributed in the West part of the Peninsular and mostly found in the rice field areas (Manley 1977). This predator species is a common predator of small arthropod pests such as the leafhoppers (Manley 1977) thrips, planthoppers and other rice pests (Kalshoven \& van der Laan 1981).

Over the years, members of the family Delphacidae (planthoppers) and Cicadelidae (leafhoppers) are major pests of rice crop, Oryza sativa Linnaeus in the agricultural ecosystem (Fujita et al. 2013). According to Hibino (1996), planthoppers and leafhoppers borne viruses have inflicted significant damage in rice production and epidemic proportions have been recorded in major rice growing countries such as in Asia. 
The incidence of these pest species caused crop losses and some are vectors of damaging plant viruses including the rice dwarf and tungro viruses (Hibino 1996; Nault \& Ammar 1989). Severe infestation of certain planthopper and leafhopper species consequently results in 'hopperburn', a condition where the rice plant turns from yellowish to brown patches of dried plants (Backus et al. 2005). This eventually can be substantial, as crops production grown for human consumption is at risk (Oerke 2006). However, as the predator's population trend followed those of crop pests, and normally start to attack immediately after germination until the reproductive phase of the rice crop (Bong et al. 2015). Paederus fuscipes showed potential as biological control agent of these rice pest species.

In order to establish the suitability of $P$. fuscipes to control the leafhoppers and planthoppers, a clear understanding of the natural enemy's preference on these pest species need to be conducted. A simple model of predator prey interaction strength is provided by the functional response to relate the predation rate to prey density. According to Jeschke et al. (2002), functional response is one of the key characteristics of a predator-prey system. It requires the estimation of two basic principles; the process of searching (searching rate or attack coefficient) of a predator and the time taken to fight, subdue and consume a prey (also known as the handling time) (Holling 1959). Holling (1959) identified three primary types of functional responses, Type I (linear, with zero intercept), Type II (convex), and Type III (sigmoidal). In general, Type II responses are mostly associated with invertebrate predators, and are the commonly observed response in the laboratory (Zuharah \& Lester 2011). To date, there is very limited information on the predator-prey interactions especially between $P$. fuscipes and the major crop pest species in Southeast Asia. Thus, it is ultimately important to be able to determine and therefore to predict $P$. fuscipes feeding behavior and their preferences on insect pests that mainly exists in the rice ecosystem, to understand the efficiency of this generalist predator as bio-control agent. This study aimed to examine $P$. fuscipes feeding behavior on three aspects based on the: functional response, prey preferences, and the predator's behavior in response to three common types of rice pest species in Malaysia; $N$. virescens, Ni. lugens and $R$. dorsalis.

\section{Materials AND Methods}

\section{COLLECTION SITE OF P. FUSCIPES AND PREY SPECIES}

Both predator and prey species were collected at the rice field areas at Jalan Sejahtera Indah (N 5 29' 06" E $\left.100^{\circ} 23^{\prime} 16^{\prime \prime}\right)$, Telok Air Tawar, Butterworth, Penang. Penang state is located at the northeastern coast of Peninsular Malaysia that experiences uniform tropical climate with consistent temperature that falls between $29^{\circ} \mathrm{C}$ and $35^{\circ} \mathrm{C}$ and high relative humidity during the daytime around the year which is suitable for $P$. fuscipes reproduction.
The distance of the study site location from Universiti Sains Malaysia, Georgetown is about $31 \mathrm{~km}$. Weeds are often found growing scattered on the boundaries of the rice fields areas. No presence of large trees found around rice fields.

\section{SAMPLING METHODS}

Paederus fuscipes beetles were captured using UV blacklight traps (Model 812, John W. Hock Company, Florida, USA) during their most active dispersal flight between 2015 and $2215 \mathrm{~h}$ (Maryam et al. 2017). Trapped beetles were collected by using a mechanical insect aspirator. Collected $P$. fuscipes were then brought back and maintained in the laboratory. Species identification was based on Lott and Anderson (2011).

By using conventional light trap methods, the adult of rice insect pests were captured in abundance: the green leafhopper, $N$. virescens; zig-zag leafhopper, $R$. dorsalis; and brown planthopper, Ni. lugens. Conventional light trap is a trap with a light bulb generated using a portable generator and hang in front of large white sheeth. Insect pests were then collected using a mechanical insect aspirator and brought back to the laboratory. Identification was done and following Wilson and Claridge (1991). The fresh batches of prey were freshly collected a day prior to the experiment.

\section{MAINTENANCE METHOD OF P. FUSCIPES}

The collected adults of $P$. fuscipes were maintained in the Medical Entomology Laboratory, Vector Control Research Unit, School of Biological Sciences, Universiti Sains Malaysia $\left(5^{\circ} 21{ }^{\prime} 21.913 " \mathrm{~N}, 100^{\circ} 18,4.575 " \mathrm{E}\right)$ at a temperature of $28 \pm 2{ }^{\circ} \mathrm{C}, 63.8 \pm 2.0 \%$ r.h. and a photoperiod of L12:D12. All subsequent experiments were conducted at the same laboratory condition. The maintenance method was adopted from Bong et al. (2012) with some modifications on the container and food provided to $P$. fuscipes. Paederus fuscipes beetles were maintained in a plastic container of $16.5 \mathrm{~cm}$ height $\times 11.5$ $\mathrm{cm}$ width in size and covered with muslin cloth to allow air ventilation as well as to prevent the beetles from escaping. A moist cotton ball was provided as water source on one side of the plastic container. On the other hand, cat foods, a good source of carbohydrate was offered to the beetles as food supply.

\section{EXPERIMENTAL DESIGNS}

\section{FUNCTIONAL RESPONSE STUDY}

The functional response of $P$. fuscipes were examined on three prey species: green leafhoppers, $N$. viruses; brown planthoppers, Ni. lugens functional; and zig-zag leafhoppers, $R$. dorsalis. These pests were chosen in this study because they are the main pests during the vegetative phase of the rice plants and were found to be the most 
abundant pests in the rice fields. A preliminary study feeding test was conducted to examine the maximum consumption rate per $24 \mathrm{~h}$ of $P$. fuscipes on different types of prey species. Premilinary study showed that the maximum number of prey consumed within $24 \mathrm{~h}$. by $P$. fuscipes was less than ten individuals. Hence, the density treatments of prey at 1, 3, 5, and 10 individuals were offered to $P$. fuscipes in separate experiments. Two prey conditions were also tested; using alive and dead (carcass) prey. Carcass of prey was included as $P$. fuscipes adults are polyphagous and also known to feed on animal matter (Frank \& Kanamitsu 1987). A total of 24 experiments were run separately crossed all three variables (prey types, prey densities, prey conditions) as stated and replicated for ten times (with total of 240 experiments). This study was adapted by Zuharah and Lester (2011) with some modifications on the number of prey densities.

A single $P$. fuscipes beetle was placed in a plastic container measuring $5.6 \mathrm{~cm}$ in length $\times 4.6 \mathrm{~cm}$ in width with a moist cotton ball on one side of the plastic container. $P$. fuscipes was starved for $24 \mathrm{~h}$ prior to the experiment. On the other side of the container, prey item of mentioned densities was placed and left for $24 \mathrm{~h}$. After $24 \mathrm{~h}$, the remaining prey item was counted and recorded. New individual of $P$. fuscipes predator and a new batch of prey were used in each separate experiment.

Using the equation by Juliano (2001), we determine the shape of the functional response which relates the proportion of prey eaten $\left(\mathrm{N}_{\mathrm{e}}\right)$ to amount of prey offered $\left(\mathrm{N}_{0}\right)$. The polynomial function was fitted to the data that describes the relationship between both prey eaten $\left(\mathrm{N}_{\mathrm{e}}\right)$ and the amount of prey offered $\left(\mathrm{N}_{0}\right)$ as follows:

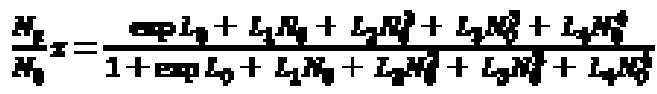

where Ne the number of prey eaten; N0 the initial number of prey available; and thus Ne/N0 is the probability an individual is eaten.

To estimate the handling time and attack rate for each prey, Roger's equation (1972) was used. The 'randompredator' equation of Rogers (1972) was best to describe the results as no prey was replaced during the course of the experiment:

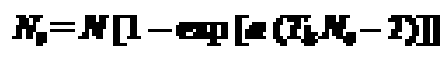

where $N_{e}$ is the number of prey eaten; $N$ is the initial number of prey available (number of prey offered); $a$ is the instantaneous attack rate; $T$ is the total available time; and $T_{h}$ is the 'handling time' (or the time required to handle a prey item). Equation 2 has been used by many studies (Zuharah \& Lester (2011)) as it permits an analysis of the functional response despite the depletion of prey by the predators. The attack coefficient, $a$ and handling time, $\mathrm{T}_{\mathrm{h}}$ were estimated from the functional response data using a standard non-linear least squares technique.

\section{Prey Preference}

The prey preference by $P$. fuscipes beetles were tested on three types of rice field pests: green leafhoppers, $N$. virescens; brown planthoppers, Ni. Lugens; and zig-zag leafhoppers, $R$. dorsalis. A single $P$. fuscipes beetle was placed in a $5.6 \mathrm{~cm}$ in height $\times 4.6 \mathrm{~cm}$ in width plastic container. In this experiment, a specific proportion of pest species was offered, and a moist cotton ball was placed at one end of the plastic container. All prey was acclimatized for $10 \mathrm{~min}$, prior to the introduction of $P$. fuscipes predator.

In this experiment, $P$. fuscipes beetle was presented with a mixture of; adults of $N$. virescens and Ni. lugens, adults of $N$. virescens and $R$. dorsalis, and adults of $N i$. lugens and $R$. dorsalis at ratios of $0: 6 ; 1: 5 ; 2: 4 ; 3: 3 ; 4: 2$; $5: 1 ; 6: 0$. The experiment was designed using two conditions of prey: alive and dead. A total of 42 experiments were run separately crossed all three variables (mixture of prey types, prey ratios, prey conditions). Each particular trial was replicated for five times (with a total of 210 experiments). Paederus fuscipes was starved for $24 \mathrm{~h}$ prior to the experiment. After $24 \mathrm{~h}$ of exposure, the remaining prey item was counted and recorded.

Prey preference was measured with a model developed by Chesson (1974) and Manly (1982) modification for the description of prey depletion. The predicted preference $(\alpha)$ for each predator was determined using attack constant from the functional response experiment using this multiplicative model as shown on Zuharah and Lester (2011):
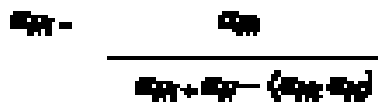

where $\alpha_{N i}$ was the predicted preference for Ni. Lugen; $\alpha_{N i}$ and $\alpha_{N}$ were the attack constants for $N i$. lugen and $N$. virescens, respectively. Equation (3) was used to predict preference of $P$. fuscipes on $R$. dorsalis. Manly's $\alpha$ ranges in value between zero and one, and the value of 0.67 represents no preference for either prey species predicted from the functional response in this study.

\section{Predator's BehaVIOR}

Capture behavior of the predator on prey was set-up in this study. Three behaviors of P. fuscipes was observed; searching frequency (the searching rate spent by foraging predator to locate the prey item at a distance for the first time before it starts capturing its prey), prey capturing (the number of attempt done by predator to finally approach and capture the selected prey with its mandibles and start feeding), and prey ingestion (the duration of time spent by predator in feeding).

Predator's general modes of locomotion in catching its prey items were observed and recorded. Here, we evaluated on how fast these predators need to search and finally start to feed on its specific prey at a duration of time spent (min.). The context 'prey ingestion' is a behavioral description for the duration of time predator beetle spent in feeding once it starts capturing its prey and held it by 
means of its mandibles until the escape movements of the prey become weary. Occasionally, the feeding process occurred in for a few times and may pause in between feeding to drink from the moist cotton. Data was recorded throughout the feeding process until the whole prey item was completely consumed or partially eaten by the predator within an hour.

If $P$. fuscipes beetle did not show any reaction towards the prey item and did not feed on it within an hour, the trial was discarded, and data were not included into the statistical analysis. Predator's searching, capturing and feeding behavior was observed on two different sets of prey conditions (alive and dead). P. fuscipes was offered with single alive or dead prey of the adult of $N$. virescens, $N i$. lugens or $R$. dorsalis in separate experiments. P. fuscipes was starved for $24 \mathrm{~h}$ prior to the experiment. A total of six treatments were done separately crossed all two variables (prey types and prey conditions). Each experiment was replicated for ten times (with a total of 60 replicates).

\section{Statistical Analysis}

To compare the differences between the number of prey ( $N$. virescens, Ni. lugens and $R$. dorsalis) and condition of prey (alive and dead) that were consumed by the $P$. fuscipes beetles, two-way ANOVA was used. Whereas, a Student's $t$-test was performed to determine any significant difference in the preference of predators between these two species tested for each experiment. The predator's behavior of searching, capturing and ingestion was all examined using the two-way analysis of variance (ANOVA). Independent variables were the types of prey species ( $N$. virescens, $N i$. lugens or R. dorsalis) and prey conditions (alive or dead). Data analyses was done using SPSS version 20.0. Normality test was conducted for all data at the 0.05 significance level by using Shapiro-Wilk test prior to two-way ANOVA analyses. If the criteria for normality were not met, the data was normalized using log transformation.

\section{RESULTS}

\section{FUNCTIONAL RESPONSE STUDY}

After determining the shape of the response curve on the plotted graph produced from the experiment, all curves showed the Type II functional response of Holling (1959). $P$. fuscipes functional response on $N$. virescens, Ni. lugens and $R$. dorsalis prey species was significantly different $(\mathrm{F}$ $=10.461 ; \mathrm{df}=2,234 ; \mathrm{P}<0.05)$. The response graph showed predator consumed significantly higher number of $R$. dorsalis prey presented alive and dead compared to other prey species $(\mathrm{P}<0.05$; Figure $1(\mathrm{~A}))$. Interestingly, $P$. fuscipes consumed a similar number of both live $R$. dorsalis and Ni. lugens except at high prey densities once $R$. dorsalis was presented in dead condition (Figure 1(A) and Figure 1(B)). Whereas, $N$. virescens was the least consumed prey species with a significantly lower number of alive and dead prey consumptions by $P$. fuscipes predator $(\mathrm{P}<0.05$; Figure $1(\mathrm{C}))$.

Overall, the consumption rate on different prey conditions presented alive and dead was found to be significantly different $(\mathrm{F}=77.896 ; \mathrm{df}=1,234 ; \mathrm{P}<0.05)$. Dead prey item was consumed in a greater number compared to alive prey (Table 1). P. fuscipes was found to have significantly higher handling time of their most consumed prey species of live $R$. dorsalis $(9.7 \pm 1.65, \mathrm{n}=$ $10)$ and lower handling time on dead $R$. dorsalis $(4.9 \pm$ $0.82, \mathrm{n}=10)$ compared to two other prey species $N$. virescens and $N i$. lugens $(\mathrm{P}<0.05)$. Interestingly, the highest attack rate on dead and alive preys presented by $P$. fuscipes predator was prominently seen on $R$. dorsalis $(0.4$ $\pm 0.03, \mathrm{n}=10)$, and Ni. lugens $(0.2 \pm 0.02, \mathrm{n}=10)$, respectively.

TABLE 1. The average number (mean \pm SE) of alive and dead prey consumed per day by $P$. fuscipes predator $(\mathrm{n}=10)$

\begin{tabular}{lcc}
\hline Prey/Prey condition & $\begin{array}{c}\text { Alive } \\
(\text { mean } \pm \mathrm{SE})\end{array}$ \\
\hline Recilia dorsalis & $2.2 \pm 0.25 \mathrm{a}$ & $3.7 \pm 0.26 \mathrm{a}$ \\
Nilaparvata lugens & $2.1 \pm 0.3 \mathrm{a}$ & $2.7 \pm 0.26 \mathrm{a}$ \\
Nephotettix virescens & $1.0 \pm 0.26 \mathrm{a}$ & $2.4 \pm 0.37 \mathrm{~b}$ \\
\hline
\end{tabular}

* Same letter represents no significant differences between row for each prey species (Student's $t$-test, $\mathrm{p}>0.05$ )

\section{Preference of Prey}

It was observed that $P$. fuscipes preferred $R$. dorsalis $>N i$. lugens $>N$. virescens. $P$. fuscipes preferred mostly to feed upon the $R$. dorsalis compared to $N$. virescens even at low number of individuals, once given a choice between this two prey species $(\mathrm{t}=2.10 ; \mathrm{df}=138 ; \mathrm{P}=0.037$; Figure 2$)$. Nevertheless, the preference of $P$. fuscipes consumption rate was primarily higher on dead $R$. dorsalis compared to the live $R$. dorsalis with $(6.2 \pm 4.60, \mathrm{n}=5)$ and $(4.7 \pm 3.55$, $\mathrm{n}=5$ ) consumed individuals.

Similar situation was also observed when $\mathrm{Ni}$. lugens was offered together with $N$. virescens, significantly higher preferences were observed on $\mathrm{Ni}$. lugens instead of $N$. virescens species $(\mathrm{t}=3.59 ; \mathrm{df}=138 ; \mathrm{P}<0.05)$. . fuscipes consumed significantly more on $\mathrm{Ni}$. lugens for both prey conditions even at proportionally fewer Ni. lugens to $N$. virescens at ratio of 1:5 (Figure 3(A)). However, dead Ni. lugens was consumed comparatively more than the alive ones at all levels except when the ratio was at 5:1. Number of dead and alive $\mathrm{Ni}$. lugens prey consumed was with means of $8.0 \pm 4.78, \mathrm{n}=5$ and $4.1 \pm 2.27, \mathrm{n}=5$ individuals correspondingly.

Interestingly, once $R$. dorsalis and $\mathrm{Ni}$. lugens prey were offered together to the $P$. fuscipes predator. No significant variation was observed between these two species ( $\mathrm{t}=1.29 ; \mathrm{df}=138 ; \mathrm{P}=0.201$; Figure 4). . fuscipes consumed both dead prey species at equal rates on 1:5 ratio. 

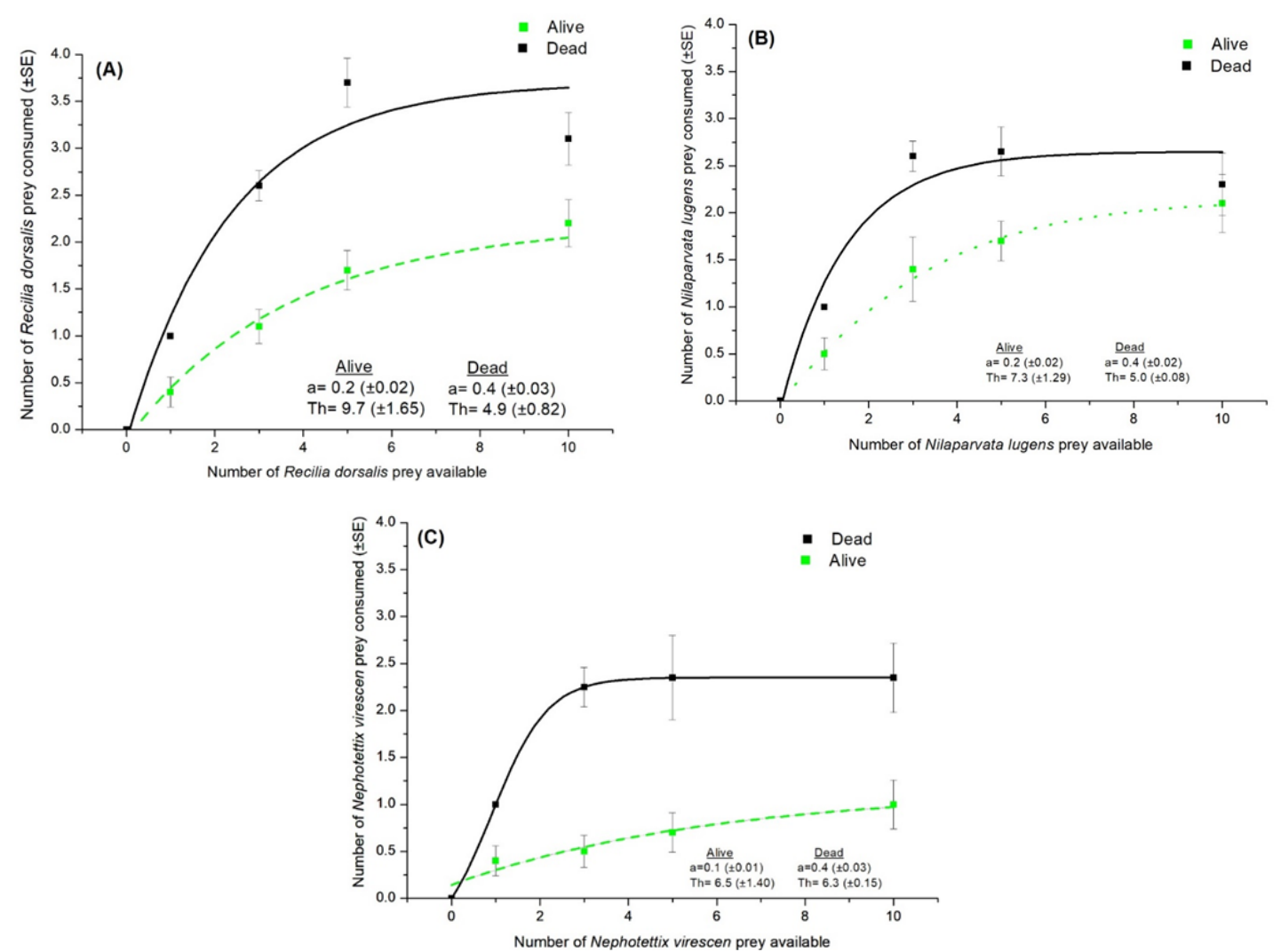

FIGURE 1. Paederus fuscipes displayed the Type II (convex) functional response model against alive and dead (A) Recilia dorsalis, (B) Nilaparvata lugens, (C) Nephotettix viscerans. Data were plotted with means of $95 \%$ confidence intervals
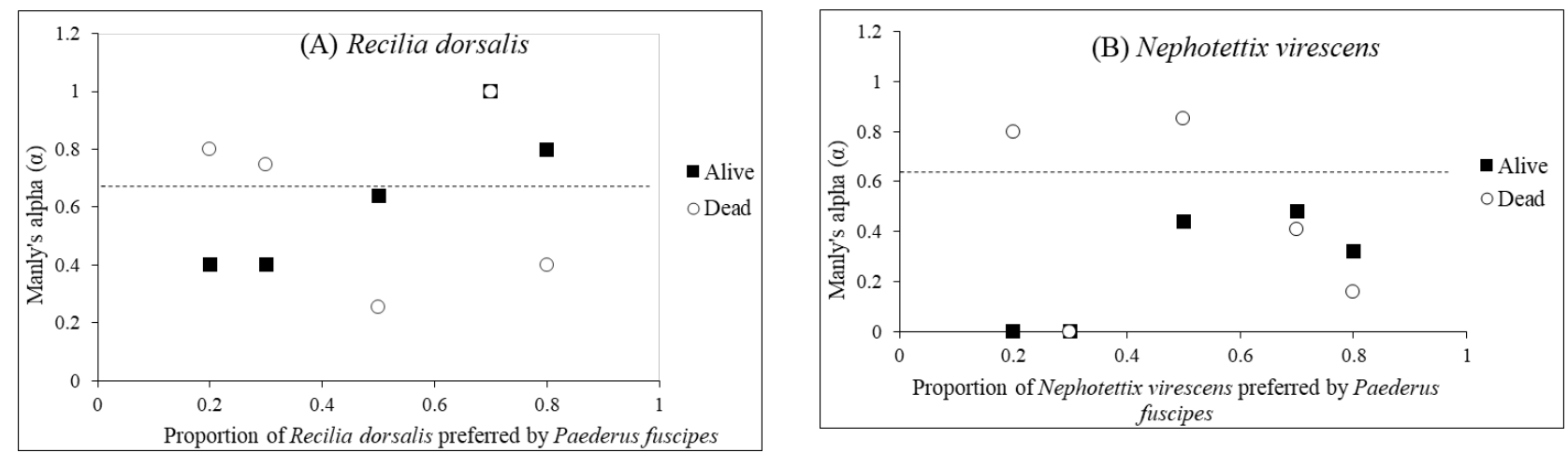

FIGURE 2. The preference of $P$. fuscipes on two combinations of prey between (A) R. dorsalis and (B) N. virescens presented alive and dead indicated by Manly's alpha $(\alpha)$ (mean). Values above $\alpha=0.67$ (defined by the broken horizontal line) indicate preference

Overall, dead prey $(6.7 \pm 3.95, \mathrm{n}=5)$ was consumed more compared with live $R$. dorsalis prey $(4.0 \pm 3.37, \mathrm{n}=5)$ (Figure 4(A)).

\section{PREDATOR's BEHAVIOR}

\section{SEARCHING BEHAVIOR FREQUENCY OF P. FUSCIPES ON ITS PREY}

The predators initially start to show searching behavior by inspecting its surrounding environment and by also stalking the potential food item at a distance. P. fuscipes then displayed a slow forward movement towards the prey while spontaneously raising the tip of their abdomen when walking, mimicking a tail-raising behavior of a threaten scorpion when it is being alarmed. The locomotion pattern of moving back and forth from the prey happened for a few minutes with a few attempts before the beetle start attacking its prey, and this is counted as searching behavior. This behavior was displayed for either alive or dead prey conditions.

The searching rate observed on the live prey of brown planthopper, Ni. lugens was with mean of $15.3 \pm 2.67, \mathrm{n}$ $=10$. While, the searching rate observed on $P$. fuscipes predator on the dead prey of green leafhopper, $N$. virescens 

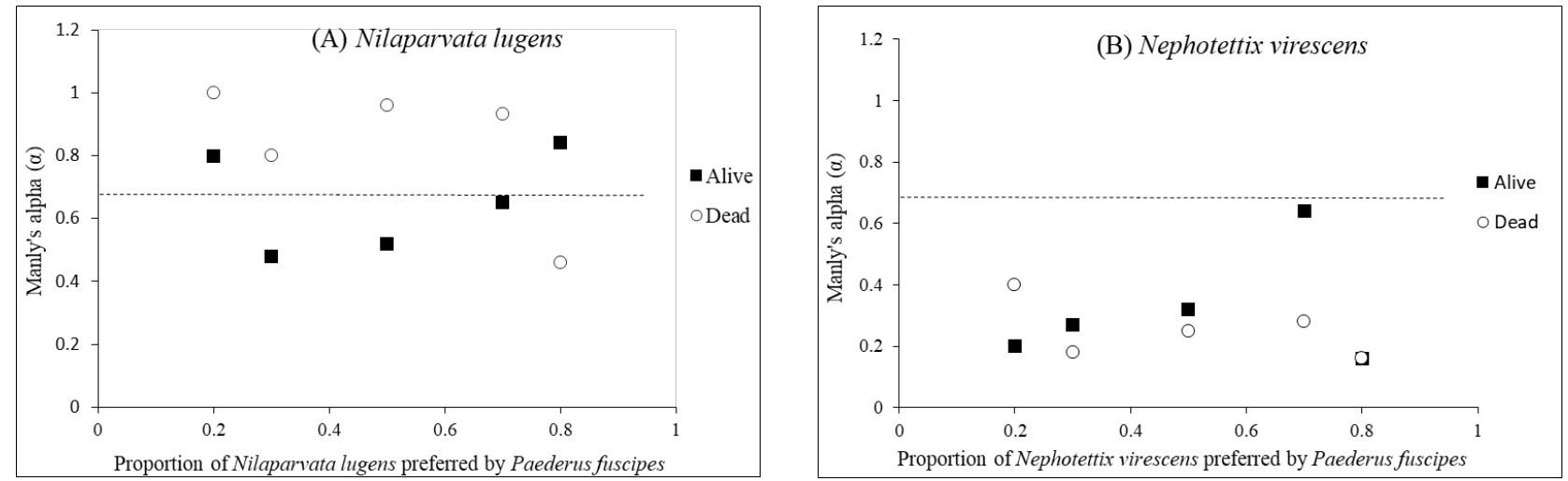

FIGURE 3. The preference of $P$. fuscipes on two combinations of prey between (A) Ni. lugens and

(B) N. virescens presented alive and dead indicated by Manly's alpha ( $\alpha$ ) (mean). Values above $\alpha=0.67$ (defined by the broken horizontal line) indicate preference
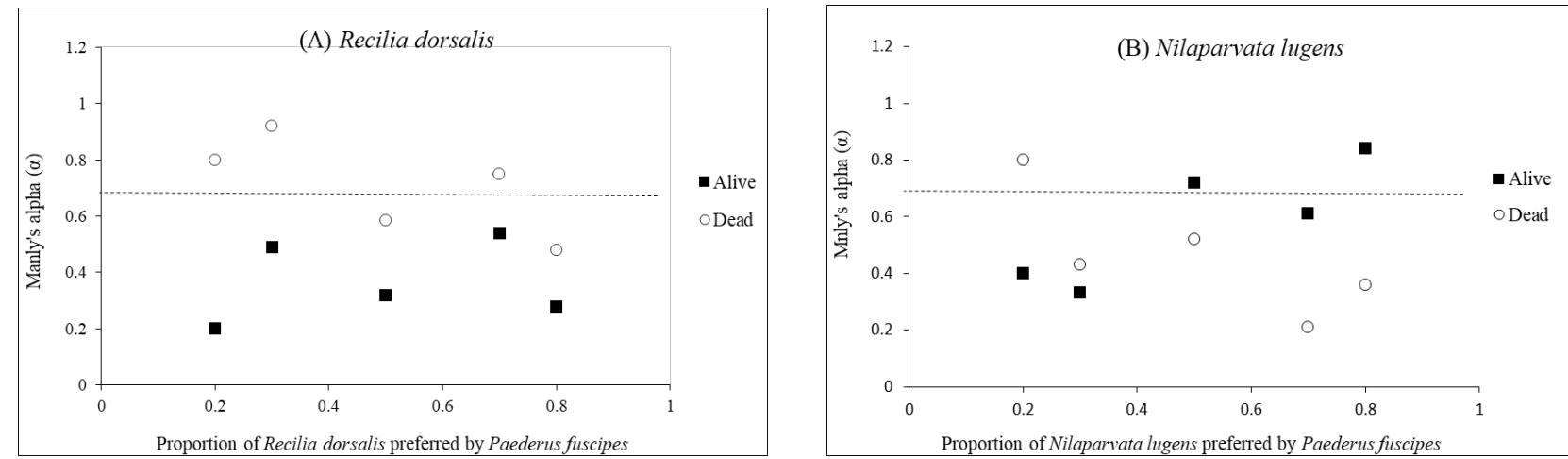

FIGURE 4. The preference of $P$. fuscipes on two combinations of prey between (A) $R$. dorsalis and

(B) Ni. lugens presented alive and dead indicated by Manly's alpha ( $\alpha$ ) (mean). Values above $\alpha=0.67$ (defined by the broken horizontal line) indicate preference

was with a mean number of $9.5 \pm 3.2, \mathrm{n}=10$. Beetle was observed to immediately attack after a short searching rate on dead prey items rather than on alive prey. However, two-way ANOVA showed no significant interaction between the types of prey species and prey conditions on the searching behavior frequency of $P$. fuscipes $(\mathrm{F}=1.530$; $\mathrm{df}=2,54 ; \mathrm{P}=0.226$; Figure $5(\mathrm{~A}))$.

\section{CAPTURING BEHAVIOR OF P. FUSCIPES ON ITS PREY}

$P$. fuscipes was seen pursuing the prey by running close to it in a series of fast runs and sudden stops for a while, and wait for the prey movement response that was presented alive or dead. The moment the predator was about to start capturing the prey, the number of attempts by the predator was counted. Generally, P. fuscipes predator displayed no significant difference on the capturing attempts for both alive and dead prey items $(\mathrm{P}>0.05$; Figure 5(B)). However, the number of attempts shown by $P$. fuscipes predator on alive $N i$. lugens prey species was with a mean number of $4.6 \pm 1.15, \mathrm{n}=10$. Based on the capturing activities of $P$. fuscipes on the dead prey items, the attempt rate observed on $N$. virescens was with a mean of $3.3 \pm 0.40, \mathrm{n}=10$. Similarly, no statistically interaction was found in the capturing behavior of $P$. fuscipes based on the types of prey species and prey conditions $(\mathrm{F}=0.841 ; \mathrm{df}=2,54 ; \mathrm{P}=$ 0.437).

FEEDING BEHAVIOR OF P. FUSCIPES ON ITS PREY

Paedarus fuscipes finally approached and quickly responded by start seizing the prey with its strong mandible while feeding on it slowly until they released it, as it is defined as the time spent on feeding behavior. Results indicated that the time spent on feeding was significant on the dead prey items compared to the alive prey $(\mathrm{P}<0.05$; Figure 6). However, no significant interaction was found on all types of prey species offered regardless of the conditions of prey items consumed by the $P$. fuscipes beetle $(\mathrm{F}=0.516, \mathrm{df}=2,54, \mathrm{P}=0.600)$. Nonetheless, $P$. fuscipes beetles are insatiable feeders that feed on both alive and dead prey items.

\section{DisCUSSION}

The present study showed that the predatory behavior of P. fuscipes followed the Type II functional response for all 

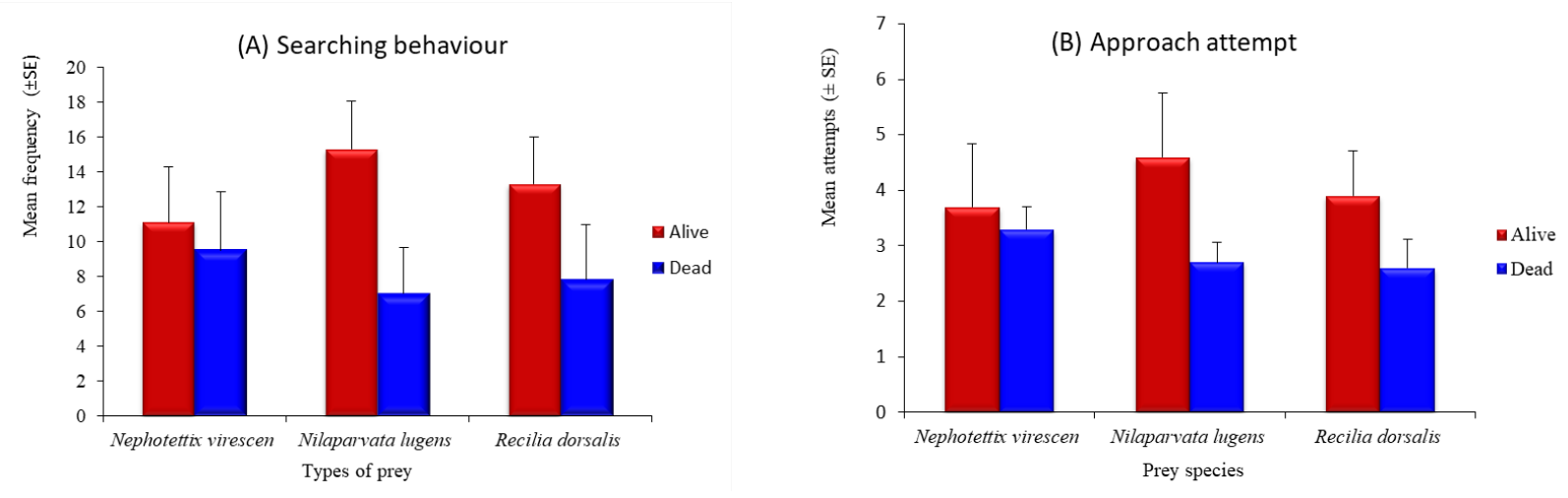

FIGURE 5. The (A) searching behavior frequency, (B) attempt to approach by $P$. fuscipes on three types of prey species ( $N$. virescens, Ni. lugens and $R$. dorsalis) presented in two conditions (alive and dead)
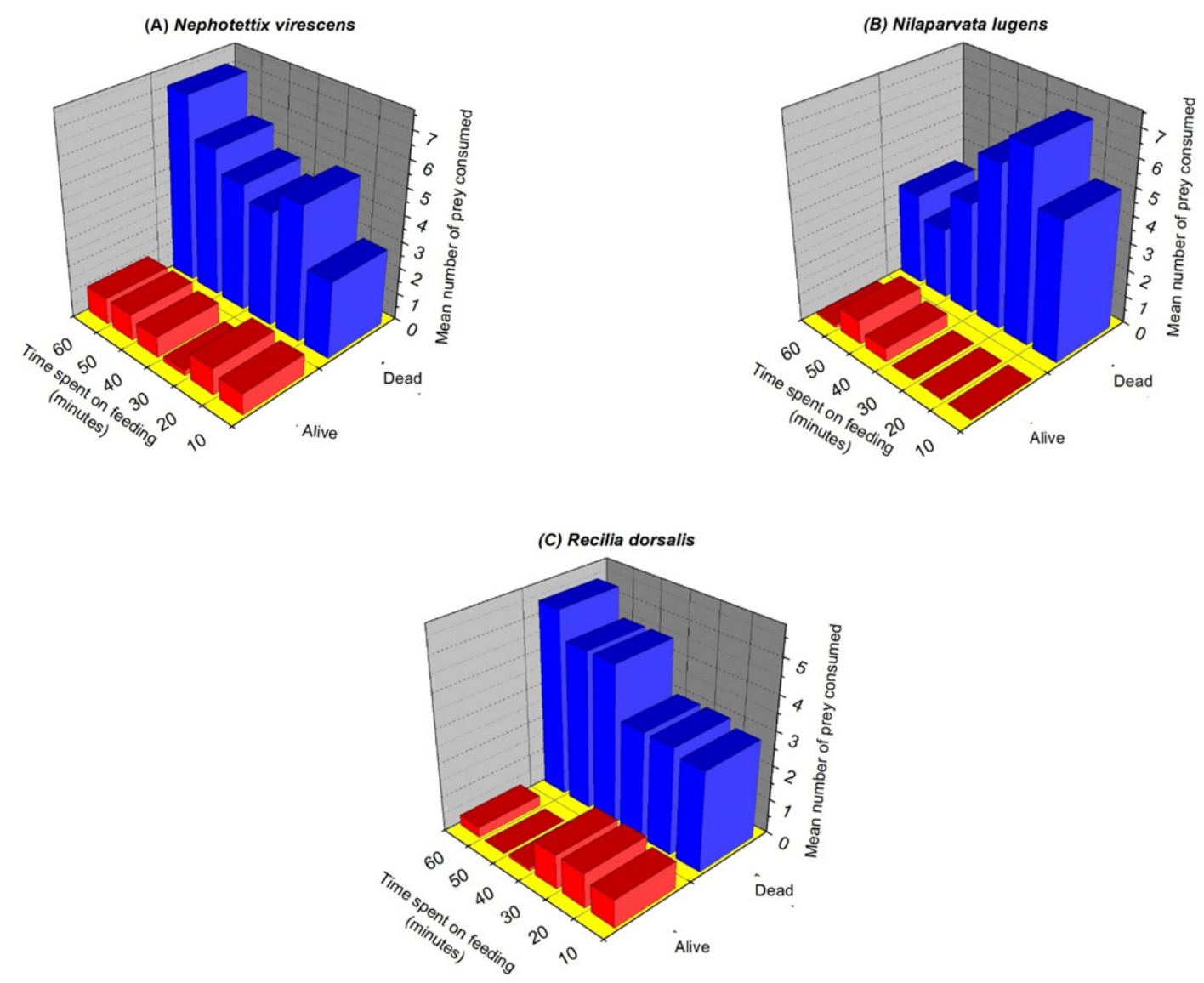

FIGURE 6. The predation behavior of $P$. fuscipes based on three types of prey species (a) N. virescens, (b) Ni. lugens, and (c) $R$. dorsalis. Prey was offered in alive and dead conditions in relation to time (min.) spent on feeding

of the three types of dead and alive prey species. Such behavior denoted that the prey consumption by P. fuscipes rises significantly but at a declining rate with an increasing number of prey densities. In a Type II response, predators are expected to capture and feed on prey without initial delay in learning ways to circumvent difficulties unlike the Type III functional response. This proposed that the offered alive and dead prey in the current study showed no defense strategies and are immobile in such a way that that the $P$. fuscipes was feeding ad libitum, not needing to improve prey intake at high prey density.
Interestingly, this exponential response curve has also been found on many other insects and arthropods species (Murdoch 1969; Xiao et al. 2013; Zuharah \& Lester 2011). According to some literatures, predators that displayed the Type II functional response are generally known as successful biological control agents (Reis et al. 2003; Timms et al. 2008; Xiao \& Fadamiro 2010). Though, Holling (1965) stated that only a Type III functional response showed by predators were able to contribute to the regulation of prey populations and allow long term persistence between predators and their prey. Hence, the 
exhibition of the Type II response by $P$. fuscipes indicated that this predator presented better potential for biological control of insect pests at low prey density. This is one of the main factors which will control the early foundation of insect pest population below the economic level once infestation of rice pest starts during the nursery stage of the rice crop.

According to Ganjisaffar and Perring (2015), even though the functional response is an important aspect of natural enemy behavior, it is not the only factor that determines the success or failure of a bio-control agent. A predator's functional response may vary under various biotic and abiotic conditions, predator numerical response, and competition amongst diverse predators present in the environment as well as its searching ground (FernándezArhex \& Corley 2003; Gontijo et al. 2012; Parajulee et al. 2006).

The study on prey preferences showed that $P$. fuscipes preferred mostly $R$. dorsalis followed by Ni. lugens when they had choices between $R$. dorsalis vs. $N$. virescens, and Ni. lugens vs. $N$. virescens. This indicate that $P$. fuscipes predators feed on a variety of prey items but preferred mostly on small and soft-bodied insects as part of their diet. They also practice scavenging besides being predacious in nature. Dead $R$. dorsalis was found to be the most consumed prey. The predator consumed the highest number of $R$. dorsalis or showed greater preference towards it due to the small size body which increased the consumption rate of $P$. fuscipes. According to Peters (1983) and Schmidt-Nielsen (1984), the bioenergetics of animals is known to be influenced by the body size. Fundamentally, if a prey item could not sustain the energy needed by the predator, the predation rate escalates, and the predator will consume or kill more prey to gain more nutrients to stay alive (Vézina 1985). The 'predation rate' is the role of proportion of predator's basic energy demands of maintenance, growth and reproduction to the energy supplied by each prey for its continuous survival chances (Schoener 1968). Kundu et al. (2014) also specified that the quantity and the characteristics of the prey species influenced the preference of predator towards a given prey type in an ecosystem.

The handling time is a good indicator of predation rate as it estimates the cumulative effect of time taken during capturing, killing, subduing, and digesting of prey items (Holling 1966, 1959). In the current study, it was discovered that the shortest handling time was observed on dead $R$. dorsalis, suggesting that $P$. fuscipes gave much stronger predatory response on defenseless and smaller prey item. The time taken to handle the dead green leafhopper, $N$. virescens was considerably higher compared to other prey species. This suggests that due to $N$. virescens being larger in size compared to Ni. lugens and $\mathrm{R}$. dorsalis. Paederus fuscipes took more time to consume $N$. virescens. According to Hoyle and Keast (1987) and Werner (1974), handling time increased rapidly with increasing prey size, and declined considerably with smaller size of prey. Thus, it is true as in the case of $P$. fuscipes feeding behavior.
However, the predator's handling time is vice versa once presented with both live $R$. dorsalis and $N$. virescens prey. The handling time rises on the offered live $R$. dorsalis, but decreased when live $N$. virescens was presented. This could be explained by the following reasons: $P$. fuscipes was able to capture $N$. virescens without difficulty as it displayed little movement due to its larger size, $P$. fuscipes sight ability increases as $N$. virescens is in green colour and bigger in size which making it more susceptible to predation compared to $R$. dorsalis. Overall, $P$. fuscipes preferentially consumed more on $R$. dorsalis and Ni. lugens prey compared to $N$. virescens. This preference was supported by the higher attack rate by predator on both prey species presented dead and alive.

$P$. fuscipes preferential selection over $R$. dorsalis and $\mathrm{Ni}$. lugens prey could also be related to the predator's size (Lafferty \& Kuris 2002). Allan et al. (1987) study on other predators showed that smaller predator normally favour smaller size prey for their consumption. Moreover, under the 'optimal foraging theory', Stephens and Krebs (1986) indicated that predators will normally select prey that gives the best energy in returns. Hence, $P$. fuscipes might have not waste their energy on relatively larger prey with hard and thick stratum such as $N$. virescens as a lot of energy is needed in handling the prey. By feeding on smaller prey items will decreased the prey handling time (Gerling et al. 1990) which subsequently increased predator's resource food intake in a shorter period of time (Nylin \& Gotthard 1998). As a general rule, P. fuscipes showed higher preference towards the smaller dead prey compared to the larger alive ones.

Overall, $P$. fuscipes spent more time focusing, and feeding on the presented dead prey item as they do not need to spend time foraging for their prey. Conversely, more effort on catching and ambushing was needed on the presented alive prey items before beetles can finally start to feed. Although once live prey was captured, beetle still need to scuffle on consuming the prey item as it is also struggling to escape. Thus, lower feeding time was shown by $P$. fuscipes for the alive prey items. Overall, the whole feeding process may last up from one to several minutes depending on the types of prey and their condition.

Basically, predator's intermittent locomotion during its searching behavior where pausing during bouts of movement that often involved in acceleration or deceleration in relation to prey movement is a unique behavior. According to Kramer and McLaughlin (2001), stops in between locomotion during searching behavior may promote retrieval from fatigue, improve prey recognition, and reduce detection by other organisms. These foraging characteristics allow $P$. fuscipes rove beetles to be an efficient predator especially to smaller insect pests.

\section{CONCLUSION}

As a conclusion, P. fuscipes beetles are predacious, and also practice scavenging in their feeding habits to gain 
adequate nutrients for their optimal fitness. This feeding trait of $P$. fuscipes is an advantage in continuing its life span in nature following its dispersal towards human settings during rice harvesting stage. For instance, $P$. fuscipes may feed on encounter phytophagous prey dead or alive that is also found in human settings due to the light attraction factor. However, P. fuscipes may be more successful in the control of small and soft-bodied crop pests at low prey density particularly during the nursery stage of rice.

\section{ACKNOWLEDGEMENTS}

We wish to thank students of Medical Entomology Laboratory, Universiti Sains Malaysia for assistance in the field. This research was funded by Research University Grant USM (1001/PBIOLOGI/811284) and graduate financial support from The Ministry of Higher Education (Malaysia) for Maryam Sufian.

\section{REFERENCES}

Allan, J. D., Flecker, A. S. \& McClintock, N. L. 1987. Prey preference of stoneflies: Sedentary vs mobile prey. Oikos 49: 323-331.

Backus, E. A., Serrano, M. S. \& Ranger, C. M. 2005. Mechanisms of hopperburn: An overview of insect taxonomy, behavior and physiology. Annual Review of Entomology 50: 125151.

Bong, L. J., Neoh, K. B., Jaal, Z. \& Lee, C. Y. 2015. Paederus outbreaks in human settings: A review of current knowledge. Journal of Medical Entomology 52: 517-526.

Bong, L. J., Neoh, K. B., Jaal, Z. \& Lee, C. Y. 2012. Life table of Paederus fuscipes (Coleoptera: Staphylinidae). Journal of Medical Entomology 49: 451-460.

Chesson, J. 1982. Estimation and analysis of parasitoid search and attack parameters from field data. Environmental Entomol. 11: 531-537.

Fernández-Arhex, V. \& Corley, J. C. 2003. The functional response of parasitoids and its implications for biological control. Biocontrol of Science and Technology 13: 403413.

Frank, J. H. \& Kanamitsu, K. 1987. Paederus sensu lato (Coleoptera: Staphylinidae): Natural history and medical importance. Journal of Medical Entomology 24: 155-191.

Fujita, D., Kohli, A. \& Horgan, F. G. 2013. Rice resistance to planthoppers and leafhoppers. Critical Review of Plant Science 32: 162-191.

Ganjisaffar, F. \& Perring, T. M. 2015. Prey stage preference and functional response of the predatory mite Galendromus flumenis to Oligonychus pratensis. Biological Control 82: $40-45$.

Gerling, D., Roitberg, B. D. \& Mackauer, M. 1990. Instarspecific defense of the pea aphid, Acyrthosiphon pisum: Influence on oviposition success of the parasite Aphelinus asychis (Hymenoptera: Aphelinidae). Journal of Insect Behaviour 3: 501-514.

Gontijo, L. M., Nechols, J. R., Margolies, D. C. \& Cloyd, R. A. 2012. Plant architecture and prey distribution influence foraging behavior of the predatory mite Phytoseiulus persimili (Acari: Phytoseiidae). Experimental and Applied Acarology 56: 23-32.
Hibino, H. 1996. Biology and epidemiology of rice viruses. Annual Review of Phytopathology 34: 249-274.

Holling, C. S. 1966. The functional response of invertebrate predators to prey density. Memoirs of Entomological Society of Canada 48: 1-86.

Holling, C. S. 1965. The functional response of predators to prey density and its role in mimicry and population regulation. Memoirs of Entomological Society of Canada 45: 1-60.

Holling, C. S. 1959. The components of predation as revealed by a study of small-mammal predation of the European Pine Sawfly. The Canadian Entomologist 91: 293-320.

Hoyle, J. A. \& Keast, A. 1987. The effect of prey morphology and size on handling time in a piscivore, the largemouth bass (Micropterus salmoides). Canadian Journal of Zoology 65: 1972-1977.

Jeschke, J. M., Kopp, M. \& Tollrian, R. 2002. Predator functional responses: Discriminating between handling and digesting prey. Ecological Monograph 72: 95-112.

Juliano, S. A. 2001. Non-linear curve fitting: Predation and functional response curve. Design and Analysis of Ecological Experiment. Oxford: Oxford University Press. pp. 178-196.

Kalshoven, L. G. E. \& Van der Laan, P. A. 1981. Pests of Crops in Indonesia. Indonesia: PT Ichtiar Baru-Van Hoeve. p. 107.

Kramer, D. L. \& McLaughlin, R. L. 2001. The behavioral ecology of intermittent locomotion. American Zoologist 41: 137-153.

Kundu, M., Sharma, D., Brahma, S., Pramanik, S., Saha, G. K. \& Aditya, G. 2014. Insect predators of mosquitoes of rice fields: Portrayal of indirect interactions with alternative prey. Journal of Entomological and Zoological Studies 2: 97-103.

Lafferty, K. D. \& Kuris, A. M. 2002. Trophic strategies, animal diversity and body size. Trends in Ecology and Evolutionary 17: 507-513.

Lott, D. A. \& Anderson, R. 2011. The Staphylinidae (rove beetles) of Britain and Ireland. Part 7 and 8: Oxyporinae, Steininae, Euaesthetinae, Pseudopsinae, Paederinae, Staphylininae. RES Handbooks for the identification of British Insects. Volume 12 part 7.

Manley, G. V. 1977. Paederus fuscipes (Coleoptera: Staphylinidae): A predator of rice fields in West Malaysia. Entomophaga 22: 47-59.

Manly, B. F. J. 1974. A model for certain types of selection experiments. Biometrics 30: 281-294.

Maryam, S., Fadzly, N. \& Zuharah, W.F. 2017. Abundance, distribution and dispersal time of Paederus fuscipes (Coleoptera: Staphylinidae) and its association to human settings. Tropical Biomedicine 34: 224-236.

Murdoch, W. W. 1969. Switching in general predators: Experiments on predator specificity and stability of prey populations. Ecological Monograph 39: 335-354.

Nault, L. R. \& Ammar, E. D. 1989. Leafhopper and planthopper transmission of plant viruses. Annual Review of Entomology 34: 503-529.

Nylin, S. \& Gotthard, K. 1998. Plasticity in life-history traits. Annual Review of Entomology 43: 63-83.

Oerke, E. C. 2006. Crop losses to pests. Journal of Agricultural Science 144: 31-43.

Parajulee, M. N., Shrestha, R. B., Leser, J. F., Wester, D. B. \& Blanco, C. A. 2006. Evaluation of the functional response of selected arthropod predators on bollworm eggs in the laboratory and effect of temperature on their predation efficiency. Environmental Entomology 35: 379-386. 
Peters, R. H. 1983. The Ecological Implications of Body Size. Cambridge: Cambridge University Press. p. 329.

Reis, P. R., Sousa, E. O., Teodoro, A. V. \& Neto, M. P. 2003. Effect of prey densities on the functional and numerical response of two species of predaceous mites (Acari: Phytoseiidae). Neotropical Entomology 32: 461-467.

Rogers, D. J. 1972. Random search and insect population models. J. Anim. Ecol. 41: 69-383.

Schmidt-Nielsen, K. 1984. Scaling: Why is Animal Size so Important? Cambridge: Cambridge University Press. p. 241.

Schoener, T. W. 1968. Size of feeding territories among birds. Ecology 49: 123-141.

Stephens, D. W. \& Krebs, J. R. 1986. Foraging Theory. Princeton: Princeton University Press. p. 247.

Timms, J. E., Oliver, T.H., Straw, N. A. \& Leather, S.R. 2008. The effects of host plant on the coccinellid functional response: Is the conifer specialist Aphidecta obliterata (L.) (Coleoptera: Coccinellidae) better adapted to spruce than the generalist Adalia bipunctata (L.) (Coleoptera: Coccinellidae)?. Biological Control 47: 273-281.

Vézina, A. F. 1985. Empirical relationships between predator and prey size among terrestrial vertebrate predators. Oecologia 67: 555-565.

Werner, E. E. 1974. The fish size, prey size, handling time relation in several sunfishes and some implications. Journal of Fish Research Board Canada 31: 1531-1536.

Wilson, M. R. \& Claridge, M. F. 1991. Handbook for the Identification of Leafhoppers and Planthoppers of Rice. Wallingford: CAB International. p. 142.

Xiao, Y. \& Fadamiro, H. Y. 2010. Functional responses and prey-stage preferences of three species of predacious mites
(Acari: Phytoseiidae) on citrus red mite, Panonychus citri (Acari: Tetranychidae). Biological Control 53: 345-352.

Xiao, Y., Osborne, L. S., Chen, J. \& McKenzie, C. L. 2013. Functional responses and prey-stage preferences of a predatory gall midge and two predacious mites with twospotted spider mites, Tetranychus urticae, as host. Journal of Insect Science 13: 8 .

Zuharah, W. F. \& Lester, P. J. 2011. Are exotic invaders less susceptible to native predators? A test using native and exotic mosquito species in New Zealand. Population Ecology 53: 307-317.

Wan Fatma Zuharah* \& Sufian Maryam

School of Biological Sciences

Universiti Sains Malaysia

11800 Minden, Penang

Malaysia

Wan Fatma Zuharah*

Vector Control Research Unit

School of Biological Sciences

Universiti Sains Malaysia

11800 Minden, Penang

Malaysia

*Corresponding author; email: wfatma@usm.my

Received: 17 October 2018

Accepted: 21 October 2019 